\title{
Emended description of Janibacter terrae, including ten dibenzofuran-degrading strains and Janibacter brevis as its later heterotypic synonym
}

\author{
Correspondence \\ Elke Lang \\ ela@dsmz.de
}

\author{
Elke Lang, ${ }^{1}$ Reiner M. Kroppenstedt, ${ }^{1}$ Jolanthe Swiderski, ${ }^{1}$ \\ Peter Schumann, ${ }^{1}$ Wolfgang Ludwig, ${ }^{2}$ Andreas Schmid ${ }^{3}$ \\ and Norbert Weiss ${ }^{1}$ \\ ${ }^{1} \mathrm{DSMZ}$ - German Collection of Microorganisms and Cell Cultures GmbH, 38124 \\ Braunschweig, Germany \\ ${ }^{2}$ Department of Microbiology, Technical University Munich, 85350 Freising, Germany \\ ${ }^{3}$ Institute of Biotechnology, National Technical University, 8093 Zürich, Switzerland
}

\begin{abstract}
Ten Gram-positive strains that degraded dibenzofuran belonged to one homogeneous cluster with common biochemical and chemotaxonomic properties. The strains included the previously described strains [Terrabacter sp.] DPO 360 and DPO 1361 and were isolated from different locations in central Europe. They all shared menaquinone MK-8 $\left(\mathrm{H}_{4}\right)$ and meso-diaminopimelic acid in the cell wall and showed the same cellular fatty acid, polar lipid and RiboPrint patterns. Chemotaxonomic properties, as well as DNA G $+\mathrm{C}$ content $(72.8 \mathrm{~mol} \%)$, were consistent with those described for the genus Janibacter. Analysis of $16 \mathrm{~S}$ rDNA sequences suggested a close relationship to Janibacter terrae and Janibacter brevis. DNA-DNA hybridization of two dibenzofuran-degrading strains (DPO 360 and DPO 1361) and the type strains of $J$. terrae and $J$. brevis revealed that these strains belong to the same species. An emended description of the species J. terrae is given. J. brevis is a later heterotypic synonym of $J$. terrae.
\end{abstract}

Bacteria that degrade dibenzofuran were isolated from different sources and several geographical areas in Germany and France (Strubel et al., 1989). Metabolism of dibenzofuran by these bacteria is initiated by angular dioxygenation of the compound (Engesser et al., 1989). Three distinct extradiol dioxygenases are involved in further degradation of the resulting metabolite 2,2',3-trihydroxybiphenyl (Schmid et al., 1997). In 1989, one of the dibenzofurandegrading strains, DPO 1361, was assigned to the genus Brevibacterium on the basis of its cell-wall composition and biochemical properties (Strubel et al., 1989). Based on the results of $16 \mathrm{~S}$ rDNA analysis and DNA-DNA hybridization, Schmid et al. (1997) proposed that strains DPO 360 and DPO 1361 were representatives of the same novel species within the genus Terrabacter. In the same year, Terrabacter (Collins et al., 1989) was grouped with the genus Intrasporangium (Kalakoutskii et al., 1967) in the novel family Intrasporangiaceae (Stackebrandt et al., 1997). Three novel genera were described within the family: Janibacter, with the sole species Janibacter limosus (Martin et al., 1997), Terracoccus (Prauser et al., 1997) and Tetrasphaera (Maszenan et al., 2000). Knoellia (Groth et al., 2002) is a

The GenBank/EMBL/DDBJ accession number for the 16S rDNA sequence of Janibacter brevis DSM $13953^{\top}$ is AJ310085. genus that is very close to the family Intrasporangiaceae. A soil isolate and two trichloroethylene-degrading strains isolated from groundwater were described, respectively, as the novel Janibacter species Janibacter terrae (Yoon et al., 2000) and Janibacter brevis (Imamura et al., 2000).

These recent developments in the taxonomy of bacteria closely related to [Terrabacter sp.] DPO 360 and DPO 1361 led us to reinvestigate the taxonomic position of the dibenzofuran-degrading isolates. Eight other dibenzofurandegrading strains were included in the study. The $16 \mathrm{~S}$ RNA gene sequences of the strains showed highest similarity to those of J. terrae and J. brevis. Reassessment of the $J$. terrae and J. brevis sequences suggested that $J$. brevis may be a synonym of $J$. terrae.

Isolation sources and geographical areas of the dibenzofurandegrading strains are shown in Table 1. Strains were isolated by enrichment cultures with dibenzofuran as the sole source of carbon and energy in the laboratory of K.-H. Engesser, University of Stuttgart. Type strains were obtained from the DSMZ (Deutsche Sammlung von Mikroorganismen und Zellkulturen). For morphological and physiological characterizations, standard methods were used. The API 50CH galleries (bioMérieux) were inoculated with AUX medium for testing utilization of substrates, and 
Table 1. Dibenzofuran-degrading strains isolated from different locations in central Europe

DSM, Deutsche Sammlung von Mikroorganismen und Zellkulturen GmbH (DSMZ), Braunschweig, Germany.

\begin{tabular}{|lll|}
\hline Strain & \multicolumn{1}{c|}{ Isolation source } & \multicolumn{1}{c|}{ Place } \\
\hline DPO 210=DSM 11213 & Wastewater treatment plant & Weil der Stadt, Germany \\
DPO 320=DSM 11345 & Forest soil & Vosges, France \\
DPO $340=$ DSM 11346 & Wastewater treatment plant & Stuttgart, Germany \\
DPO 360=DSM 11214 & Contaminated soil from a coke oven & Northern Germany \\
DPO 400=DSM 11215 & Contaminated soil from an industrial site & Southern Germany \\
DPO 410=DSM 11216 & Contaminated soil from an industrial site & Southern Germany \\
DPO 420=DSM 11217 & Contaminated soil from an industrial site & Southern Germany \\
DPO 430=DSM 11218 & Contaminated soil from an industrial site & Southern Germany \\
DPO 440=DSM 11219 & Contaminated soil from an industrial site & Southern Germany \\
DPO $1361=$ DSM 11220 & Water of River Rhine & Leverkusen, Germany \\
\hline
\end{tabular}

with CHB medium (both media by bioMérieux) for testing acid production from carbohydrates. API 20NE galleries (bioMérieux) were read after 1 and 3 days and API 50CH after $1,2,3,6$ and 14 days incubation at $28^{\circ} \mathrm{C}$. Results were scored as positive when turbidity was visible after 6 days at the latest and was confirmed after 14 days. Utilization of carbon sources was tested in a mineral medium (Stanier et al., 1966) with $2 \mathrm{~g} \mathrm{l}^{-1}$ of the respective carbon source. Cultures were read after incubation for up to 28 days.

Isoprenoid quinones were extracted and purified by using the small-scale integrated procedure of Minnikin et al. (1984) and separated by HPLC (Kroppenstedt, 1985). Polar lipids were extracted, examined by two-dimensional TLC and identified according to procedures described by Minnikin et al. (1984). For analysis of fatty acids, cells were grown on tryptic soy broth agar (TSBA) for $24 \mathrm{~h}$. Fatty acid methyl esters were obtained from $40 \mathrm{mg}$ (wet wt) cells by saponification, methylation and extraction, as described previously (Kämpfer \& Kroppenstedt, 1996) and separated by a model 5898A gas chromatograph (Hewlett Packard). Peaks were integrated automatically and fatty acid names and percentages were determined by using the Microbial Identification standard software package (Sasser, 1990). Preparation of cell walls and determination of peptidoglycan structure were carried out by using methods described by Schleifer \& Kandler (1972), with the modification that TLC on cellulose sheets was used instead of paper chromatography.

Riboprinting was done by the RiboPrinter Microbial Characterization system (Qualicon) according to the manufacturer's instructions, after cleavage with endonuclease PvuII.

DNA base composition was determined by HPLC. DNA was isolated after cell disruption with a French pressure cell and purified on hydroxyapatite, according to Cashion et al. (1977). P1 hydrolysis and nucleotide dephosphorylization with alkaline phophatase were done as described by Mesbah et al. (1989). HPLC conditions (LKB equipment with Shimadzu CR-3A integrator) on a Nucleosil 100-5C18 column were chosen according to Tamaoka \& Komagata
(1984). DNA-DNA hybridization was carried out at $66^{\circ} \mathrm{C}$ as described by De Ley et al. (1970) with the modifications described by Huss et al. (1983), by using a GILFORD system model 2600 spectrophotometer equipped with a GILFORD model 2527-R thermoprogrammer and plotter. Renaturation rates were computed with the TRANSFER.BAS program (Jahnke, 1992). After amplification of the 16S rDNA of DSM $13876^{\mathrm{T}}$, purified PCR products were sequenced and electrophoresed and the sequences were aligned as decribed previously (Rainey et al., 1996). The following 16S rDNA sequences were used for alignments (Rainey et al., 1996; Schmid et al., 1997): strain [Terrabacter sp.] DPO 1361 (Y08853), J. brevis IAM $14781^{\mathrm{T}}$ (AB016438), J. terrae $\mathrm{KCCM} 80001^{\mathrm{T}}$ (AF176948) and J. limosus DSM $11140^{\mathrm{T}}$ (Y08539).

All ten dibenzofuran-degrading strains formed one cluster with high similarities in their physiology and chemotaxonomically relevant cell components. On TSBA, the DPO strains formed opaque, yellow-whitish colonies with entire edges. Colony diameter varied between 0.1 and $0.4 \mathrm{~mm}$ after 3 days and between 0.6 and $1 \mathrm{~mm}$ after 6 days incubation at $28{ }^{\circ} \mathrm{C}$. Cells were Gram-positive, non-motile, non-spore-forming cocci or rods. Cells of strain DPO 360 were irregular cocci of $0 \cdot 6-1 \cdot 4 \mu \mathrm{m}$ that occurred singly or in pairs. Cells of strain DPO 1361 were egg-shaped rods of $0.7-0.8 \times 1 \cdot 4-2.3 \mu \mathrm{m}$. The strains grew aerobically at 28 and $35^{\circ} \mathrm{C}$. Growth at $37^{\circ} \mathrm{C}$ on TSBA was poorer than at lower temperatures. Physiological properties, as determined in API 20NE and 50CH galleries, were highly similar for all ten strains. The strains reduced nitrate to nitrite, hydrolysed gelatin and utilized malate, fructose and turanose. Oxidase reaction of young cultures was negative and of 3-day-old cultures was delayed and weak. Inositol and sucrose (with one exception) and gluconate and trehalose (with two exceptions) were used. Variable results were achieved for the utilization of glucose, $N$-acetylglucosamine, maltose and adipate. All other tests in the API galleries were negative. No acid was produced from carbohydrates in the API 50CH system. The Biolog carbon source utilization test system was not applicable to the strains, as 
they gave a relatively strong reaction without a carbon source (reference vial). Physiological properties of strains DPO 360 and DPO 1361, which were selected as reference strains, and of J. brevis DSM $13953^{\mathrm{T}}$, J. terrae DSM $13876^{\mathrm{T}}$ and J. limosus strains are shown in Table 2.

Table 2. Biochemical properties of strains DPO 360 and DPO 1361, Janibacter brevis, Janibacter terrae and Janibacter limosus

Taxa: 1, strain DPO 360 (=DSM 11214); 2, strain DPO 1361 (=DSM 11220); 3, J. brevis DSM $13953^{\mathrm{T}} ; 4$, J. terrae DSM $13876^{\mathrm{T}}$; 5, J. limosus DSM $11140^{\mathrm{T}} ; 6$, J. limosus DSM 11141. $\mathrm{W}$, Weak reaction; $\mathrm{D}$, delayed reaction; ND, not determined. The following tests showed positive results for all six strains: catalase, decomposition of casein and starch, growth in the presence of $10 \% \mathrm{NaCl}$, reduction of nitrate to nitrite ${ }^{*}$ and utilization of turanose and DL-malate. All strains were negative for oxidase, motility, indole from tryptophan, arginine dihydrolase, urease, decomposition of Tween 80 and aesculin, Voges-Proskauer, acid from glucose and $\beta$-galactosidase*. Strains DSM 11214, DSM 11220, DSM $11140^{\mathrm{T}}$ and DSM 1141 did not utilize cellobiose, aconitate, $m$ - or $p$-hydroxybenzoate, citrate, succinate, DL-tartrate, ethanolamine, histamine, sarcosine, spermine, $\beta$-alanine, L-arginine, L-leucine, L-ornithine or L-valine.

\begin{tabular}{|c|c|c|c|c|c|c|}
\hline Property & 1 & 2 & 3 & 4 & 5 & 6 \\
\hline Growth at $37^{\circ} \mathrm{C}$ (on TSBA) & + & + & + & $\mathrm{W}$ & - & - \\
\hline Decomposition of gelatin ${ }^{\star}$ & + & + & $\mathrm{D}$ & $\mathrm{D}$ & - & - \\
\hline Production of $\mathrm{H}_{2} \mathrm{~S}$ from cysteine & $\mathrm{w}$ & $\mathrm{w}$ & - & - & + & + \\
\hline \multicolumn{7}{|l|}{ Utilization of: } \\
\hline D-Fructose $\dagger$ & + & + & + & + & + & - \\
\hline D-Glucose $\dagger$ & - & + & + & + & + & + \\
\hline Maltose $\dagger$ & - & + & $\mathrm{D}$ & $\mathrm{D}$ & + & + \\
\hline D-Mannose $\dagger$ & - & $\mathrm{W}$ & - & + & $\mathrm{W}$ & - \\
\hline Sucrose $\dagger$ & + & + & + & + & + & - \\
\hline Trehalose $\dagger$ & - & + & + & $\mathrm{D}$ & + & + \\
\hline Turanose $\dagger$ & + & + & + & $\mathrm{D}, \mathrm{W}$ & + & + \\
\hline Inositol $\dagger$ & $\mathrm{W}$ & + & + & + & $\mathrm{W}$ & + \\
\hline$N$-Acetylglucosamine $\dagger$ & - & + & - & $\mathrm{D}$ & $\mathrm{D}$ & - \\
\hline Gluconate $\dagger$ & + & + & $\mathrm{D}$ & + & + & - \\
\hline Sucrose & + & + & $\mathrm{ND}$ & $\mathrm{ND}$ & + & + \\
\hline Acetate & $\mathrm{W}$ & - & + & + & - & - \\
\hline Aconitate & - & - & $\mathrm{ND}$ & $\mathrm{ND}$ & - & - \\
\hline Benzoate & - & + & + & + & + & + \\
\hline Formiate & + & - & $\mathrm{ND}$ & $\mathrm{ND}$ & + & + \\
\hline Gluconate & + & + & + & + & + & - \\
\hline Hippurate & + & + & + & + & - & $\mathrm{D}$ \\
\hline D-Malate & - & - & $\mathrm{W}$ & $\mathrm{w}$ & - & - \\
\hline Putrescine & + & - & $\mathrm{ND}$ & ND & + & - \\
\hline L-Glutamine & $\mathrm{W}$ & $\mathrm{W}$ & ND & ND & $\mathrm{W}$ & w \\
\hline L-Histidine & $\mathrm{W}$ & + & $\mathrm{ND}$ & $\mathrm{ND}$ & $\mathrm{W}$ & + \\
\hline L-Proline & $\mathrm{W}$ & $\mathrm{W}$ & ND & $\mathrm{ND}$ & $\mathrm{W}$ & w \\
\hline
\end{tabular}

${ }^{*}$ API 20 NE gallery.

$\dagger$ API $50 \mathrm{CH}$ gallery.
Whole-cell fatty acid patterns of the ten DPO strains were highly similar. The main fatty acids were iso-branched (14-methylpentadecanoic acid) and cis-unsaturated fatty acids (cis 9-heptadecenoic and cis 9-octadecenoic acids), with minor amounts of iso-branched, methylated or straight-chain fatty acids (Table 3 ). The fatty acid pattern of the Janibacter strains tested was composed of the same main components, with the exception that J. limosus DSM $11140^{\mathrm{T}}$ contained $15 \%$ heptadecanoic acid as one main component. The type strain of Terrabacter tumescens differed in having only $3 \% 14$-methylpentadecanoic acid and high proportions (14\%) of hexadecanoic acid and cis 9-hexadecenoic acid (data not shown).

DPO strains 360, 340, 400, 430 and 1361 contained tetrahydrogenated menaquinone MK- $8\left[\mathrm{MK}-8\left(\mathrm{H}_{4}\right)\right]$ as the main quinone and the polar lipids diphosphatidylglycerol, phosphatidylglycerol and phosphatidylinositol. Purified cell walls of strains DPO 360 and DPO 1361 contained, besides muramic acid and glucosamine, the amino acids mesodiaminopimelic acid, glutamic acid and alanine in a molar ratio of $1: 1: 2$, respectively. Fingerprints of the partial hydrolysate were compatible with the peptidoglycan type A1 $\gamma$ m-Dpm-direct.

On the molecular side, unity of the DPO strains was confirmed by RiboPrinter patterns. All DPO strains and J. brevis DSM $13953^{\mathrm{T}}$ showed two main fragments with molecular masses of about $7 \cdot 5$ and $10.5 \mathrm{kbp}$ after cleavage with PvuII. The patterns of $J$. terrae DSM $13876^{\mathrm{T}}$ and J. limosus DSM $11140^{\mathrm{T}}$ were also dominated by two fragments that, however, had different molecular masses.

The $16 \mathrm{~S}$ rDNA sequence of DPO 1361 was $>99 \%$ similar to the deposited sequences of J. brevis IAM $14781^{\mathrm{T}}$ and J. terrae KCCM $80001^{\mathrm{T}}$. The deposited sequences of J. brevis IAM $14781^{\mathrm{T}}$ and $J$. terrae KCCM $80001^{\mathrm{T}}$ showed $99 \cdot 8 \%$ similarity to each other. Resequencing of the $16 \mathrm{~S}$ rDNA of the type strain of $J$. brevis (AJ310085) gave a sequence that was $99 \cdot 9 \%$ similar to those of J. terrae and strain DPO 1361.

DNA-DNA reassociation of the type strains of J. brevis and J. terrae resulted in $80.6 \%$ relatedness. Strain DPO 360 showed $82,94 \cdot 5,78 \cdot 9$ and $86 \cdot 2 \%$ relatedness to DPO 1361 , DPO 400, J. brevis DSM $13953^{\mathrm{T}}$ and J. terrae DSM $13876^{\mathrm{T}}$, respectively. DNA-DNA relatedness between DPO 360 and J. limosus DSM $11140^{\mathrm{T}}$ and DSM 11141 was $14 \cdot 7$ and $5 \cdot 4 \%$, respectively. The DNA G + C content of strain DPO 360 was $72 \cdot 8 \mathrm{~mol} \%$.

Whole-cell fatty acid analysis and riboprinting, together with Gram-staining, cell morphology and biochemical properties, revealed that all dibenzofuran-degrading strains belonged to one cluster. When fatty acid data were compared by Ward's method, fatty acid composition of the DPO strains was more similar within the group than to those of other bacteria included in this study or registered in the MIDI database. DPO 210 and DPO 360 showed the most atypical fatty acid patterns within the group; the fatty 
Table 3. Fatty acid contents (\%) of DPO strains and the most similar species in the genera Janibacter and Nocardioides

Taxa: 1, DPO strains $(n=10) ; 2$, DPO 360 (=DSM 11214); 3, J. brevis DSM 13953 ${ }^{\mathrm{T}}$; 4, J. terrae DSM 13876 ${ }^{\mathrm{T}}$; 5, J. limosus DSM $11140^{\mathrm{T}}$; 6, J. limosus DSM 11141; 7, N. jensenii DSM 20641 ${ }^{\mathrm{T}}$; 8, N. simplex DSM 20130 ${ }^{\mathrm{T}}$. -, Not detected.

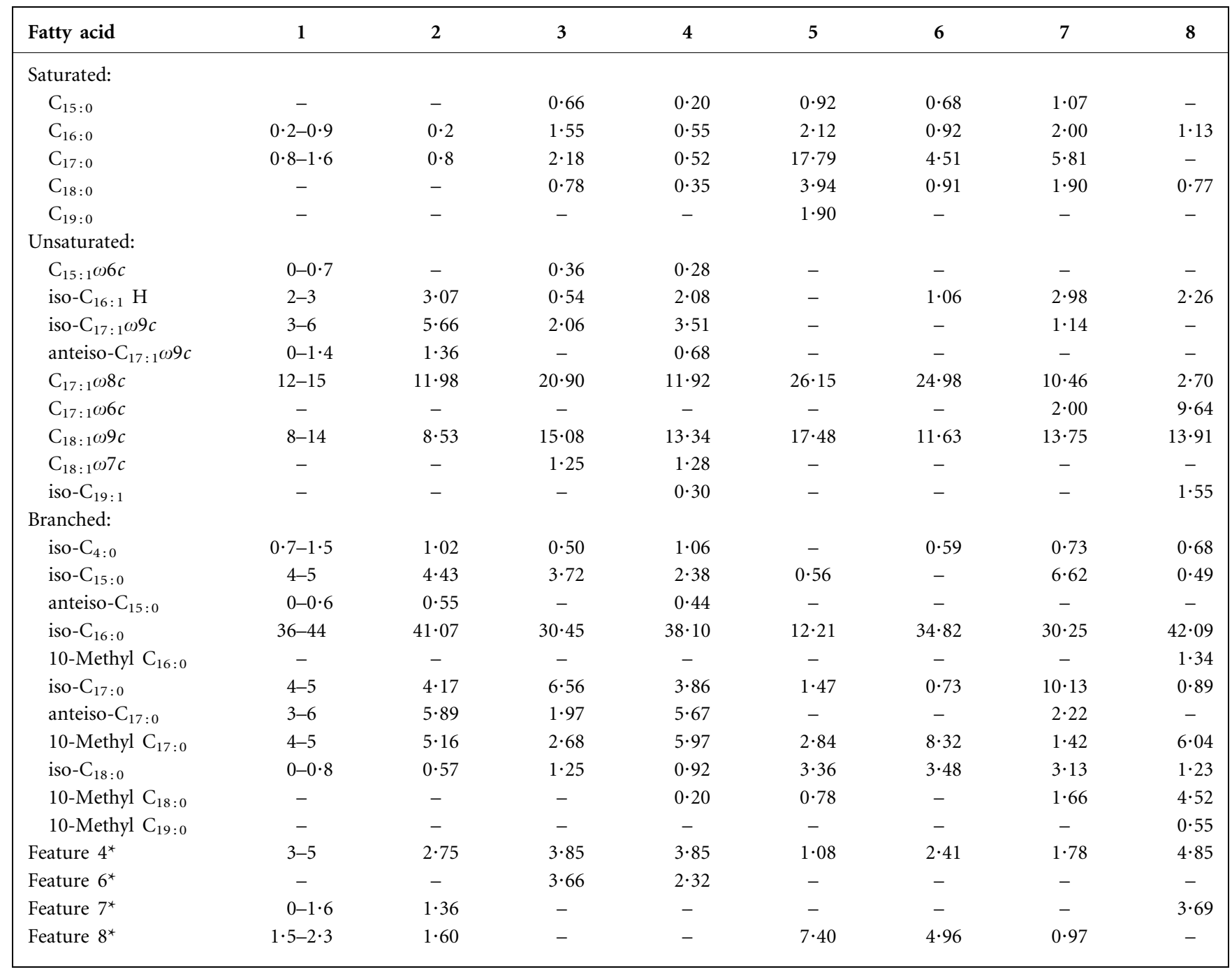

${ }^{\star}$ Unknown fatty acids; these compounds have no names listed in the Peak Library File of the MIDI system and therefore were not identified or included in percentage calculation.

acid patterns of the DPO strains were most similar to those of J. brevis DSM $13953^{\mathrm{T}}$, J. terrae DSM $13876^{\mathrm{T}}$, J. limosus DSM 11141, Nocardioides jensenii DSM 20641 ${ }^{\mathrm{T}}$ and Nocardioides simplex DSM $20130^{\mathrm{T}}$. Iso-hexadecanoic acid was the predominant fatty acid in these strains. The fatty acid pattern of the type strain of J. limosus was less similar, with a Euclidian distance of more than 30 units to the DPO cluster, and was dominated by straight-chain unsaturated acids. The group of J. brevis, J. terrae and DPO strains may be differentiated from J. limosus by the presence of iso-cis 8-heptadecenoic and anteiso-heptadecanoic acids, which are absent in J. limosus.

Like the fatty acid patterns, the carbohydrate pattern showed high homogeneity within the DPO group and between the
DPO group and the type strains of J. brevis, J. terrae and J. limosus. All utilized a limited range of the carbohydrates tested (Table 2). Forty substrates (mostly carbohydrates) that are not mentioned in Table 2 were tested in the API $50 \mathrm{CH}$ and API 20NE galleries and gave no growth. Only fructose, turanose and inositol were metabolized by all strains. Additionally, almost all strains utilized gluconate and sucrose (with the exception of J. limosus DSM 11141) and trehalose (with the exception of strain DPO 360) (Table 2). Of the carbon acids and amines additionally tested, benzoate, DL-malate, L-glutamine, L-histidine and L-proline were utilized (Table 2). Strains of the DPOJ. brevis-J. terrae cluster may be differentiated from J. limosus by their ability to grow at $37^{\circ} \mathrm{C}$ on TSBA and to hydrolyse gelatin. 
RiboPrinter patterns are generally species-specific and, in some cases, specific even to the subspecies level. Therefore, the patterns can be used for identification at the species level and, for some taxa, for clustering of strains that belong to the same species. RiboPrinter patterns of the DPO strains homogeneously showed the same two main bands (Fig. 1). The pattern of J. brevis DSM $13953^{\mathrm{T}}$ also showed the same main fragments. Only the patterns of DSM 11219 and J. brevis DSM $13953^{\mathrm{T}}$ displayed minor differences when compared to the patterns of the other strains. Nevertheless, the RiboPrints of the strains mentioned were highly similar (similarity $>0 \cdot 90$, as computed by the RiboPrinter system) and belonged to one cluster. The patterns of J. terrae DSM $13876^{\mathrm{T}}$ and J. limosus DSM $11140^{\mathrm{T}}$ corresponded to the patterns of the DPO cluster in being dominated by only two fragments. One band of the DSM $13876^{\mathrm{T}}$ pattern corresponded to the DPO pattern, but its second fragment was shifted towards a lower molecular mass. Neither of the bands of J. limosus DSM $11140^{\mathrm{T}}$ corresponded to those of the DPO cluster. The RiboPrinter data suggest that the DPO strains and J. brevis DSM $13953^{\mathrm{T}}$ form a homogeneous cluster. As physiological tests, 16S rDNA sequence analysis and DNA-DNA similarity data (see below) support the affiliation of the DPO strains and the type strains of J. brevis and J. terrae to the same species, the difference of one band in the RiboPrinter pattern of strain J. terrae DSM $13876^{\mathrm{T}}$ should be considered as a strain-specific feature.

In 1997, strains DPO 360 and DPO 1361 were assigned to the genus Terrabacter by Schmid et al. (1997), as their $16 \mathrm{~S}$ rDNA sequences were most related $(95.9 \%)$ to the sequence of T. tumescens at that time. Because of their DNA-DNA reassociation results, the authors stated that

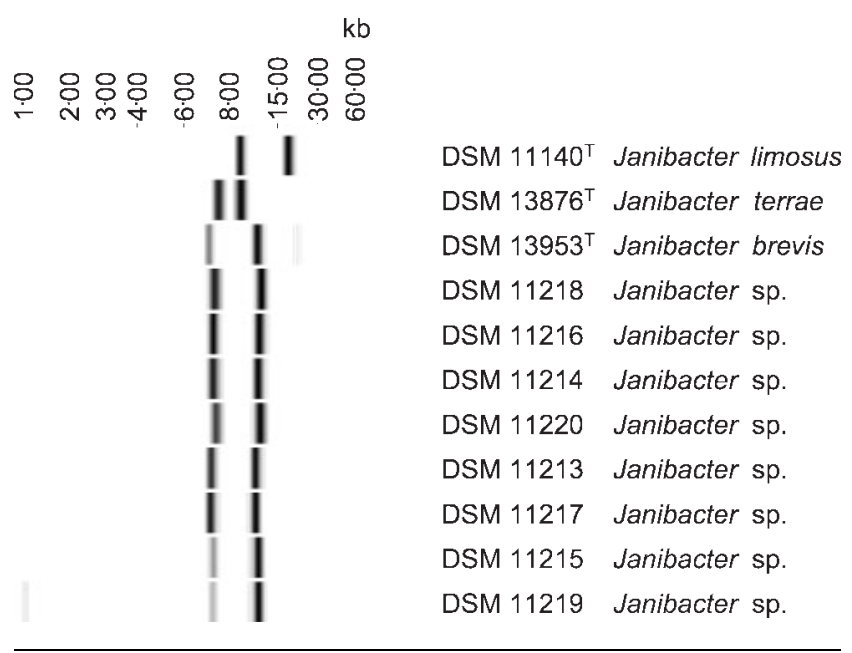

Fig. 1. RiboPrinter patterns of dibenzofuran-degrading strains and of J. limosus DSM $11140^{\top}$, J. terrae DSM $13876^{\top}$ and J. brevis DSM $13953^{\top}$, after digestion of DNA with endonuclease Pvull. the two strains belonged to one novel species that was different from $T$. tumescens. It is only since then that the genus Janibacter (Martin et al., 1997) and the family Intrasporangiaceae (Stackebrandt et al., 1997) have been described. Sanguibacter (Fernández-Garayzábal et al., 1995) and Ornithinicoccus (Groth et al., 1999) are related closely to the family Intrasporangiaceae, but now are reclassified as a family on its own or as a genus separate from the Intrasporangiaceae, respectively (Stackebrandt \& Schumann, 2000). The results of our polyphasic approach consistently suggest that the DPO strains belong to the genus Janibacter and are indistinguishable from the species J. brevis and J. terrae. These two species and the DPO strains showed the same biochemical and chemotaxonomic features [directly cross-linked meso-diaminopimelic acid as the peptidoglycan type, diphosphatidylglycerol, phosphatidylglycerol and phosphatidylinositol as polar lipids and menaquinone MK-8( $\left.\mathrm{H}_{4}\right)$ ]. Correspondence of chemotaxonomic and biochemical data was confirmed by the high similarity of $16 \mathrm{~S}$ rDNA sequences and DNA-DNA reassociation values $>78 \%$ between DPO 360, DPO 1361 and the type strains of J. terrae and J. brevis.

The species J. brevis and J. terrae were described at the same time by different working groups (Imamura et al., 2000; Yoon et al., 2000). Both were isolated from environmental samples. Our hybridization of the DPO strains and the type strains of the two species revealed $>78 \%$ relatedness to each of them. This prompted us to hybridize the DNA of the type strains of J. brevis DSM $13953^{\mathrm{T}}$ and J. terrae DSM $13876^{\mathrm{T}}$. These two were also about $80 \%$ similar. After resequencing the $16 \mathrm{~S}$ rDNA of $J$. terrae DSM $13876^{\mathrm{T}}$, the 16S rDNA sequence similarity between $J$. brevis IAM $14781^{\mathrm{T}}$ and J. terrae DSM $13876^{\mathrm{T}}$ was $99 \cdot 9 \%$. Therefore, we suggest that J. brevis and J. terrae are synonyms for one species. The effective description of J. terrae was published on pp. 1821-1827 of volume 50 of the International Journal of Systematic and Evolutionary Microbiology, whereas J. brevis was published on pp. 1899-1904 of the same volume (Imamura et al., 2000; Yoon et al., 2000). According to Rule 24b of the International Code of Nomenclature of Bacteria, the name J. terrae has priority and J. brevis should be recognized as the later synonym of the species.

\section{Emended description of Janibacter terrae Yoon, Lee, Kang, Kho, Kang and Park 2000 (syn. Janibacter brevis Imamura, Ikeda, Yoshida and Kuraishi 2000)}

Cells are Gram-positive, non-motile, non-spore-forming cocci or short rods that occur singly, in short chains or in clumps. Colonies on complex media are white, cream or yellowish, opaque, glistening and convex with entire margins. Optimal growth temperature is $25-30^{\circ} \mathrm{C}$. Maximum growth temperature on solid TSBA medium is $37^{\circ} \mathrm{C}$ and in liquid $\mathrm{R}$ medium is $40^{\circ} \mathrm{C}$. Young cultures are oxidase-negative; a weakly positive reaction may occur with older cultures or on special media. Catalase-positive. Decomposes casein, gelatin and starch. $\mathrm{H}_{2} \mathrm{~S}$ may be 
produced from cysteine. Grows in brain heart infusion in the presence of $10 \% \mathrm{NaCl}$. Reduces nitrate to nitrite. Negative results for indole production from tryptophan, acetoin production, arginine dihydrolase, urease, $\beta$ galactosidase and decomposition of Tween 80 and aesculin. No acid is produced from glucose or other carbohydrates. Variable results with glucose, mannose, maltose, $\mathrm{N}$-acetylglucosamine, benzoate, acetate, adipate and putrescine as substrate. Most or all strains utilize fructose, turanose, sucrose, trehalose, inositol, malate and gluconate. Chemotaxonomic characteristics are as described by Yoon et al. (2000) and Imamura et al. (2000). DNA G + C content is $69 \cdot 0-72 \cdot 8 \mathrm{~mol} \%$.

The type strain is $\mathrm{CS}_{12} 2^{\mathrm{T}}\left(=\mathrm{KCCM} 80001^{\mathrm{T}}=\mathrm{JCM} 10705^{\mathrm{T}}=\right.$ DSM $13876^{\mathrm{T}}$ ). All strains are isolated from environmental samples such as soil and water. Many strains are able to degrade environmental pollutants.

\section{Acknowledgements}

We thank Petra Hobeck, Gabriele Pötter and Anika Vester for excellent technical assistance. We are grateful to K.-H. Engesser for letting us have the DPO strains.

\section{References}

Cashion, P., Holder-Franklin, M. A., McCully, J. \& Franklin, M. (1977). A rapid method for the base ratio determination of bacterial DNA. Anal Biochem 81, 461-466.

Collins, M. D., Dorsch, M. \& Stackebrandt, E. (1989). Transfer of Pimelobacter tumescens to Terrabacter gen. nov. as Terrabacter tumescens comb. nov. and of Pimelobacter jensenii to Nocardioides as Nocadioides jensenii comb. nov. Int J Syst Bacteriol 39, 1-6.

De Ley, J., Cattoir, H. \& Reynaerts, A. (1970). The quantitative measurement of DNA hybridization from renaturation rates. Eur J Biochem 12, 133-142.

Engesser, K.-H., Strubel, V., Christoglou, K., Fischer, P. \& Rast, H. G. (1989). Dioxygenolytic cleavage of aryl ether bonds: 1,10dihydro-1,10-dihydroxyfluoren-9-one, a novel arene dihydrodiol as evidence for angular dioxygenation of dibenzofuran. FEMS Microbiol Lett 65, 205-209.

Fernández-Garayzábal, J. F., Dominguez, L., Pascual, C., Jones, D. \& Collins, M. D. (1995). Phenotypic and phylogenetic characterization of some unknown coryneform bacteria isolated from bovine blood and milk: description of Sanguibacter gen. nov. Lett Appl Microbiol 20, 69-75.

Groth, I., Schumann, P., Martin, K., Schuetze, B., Augsten, K., Kramer, I. \& Stackebrandt, E. (1999). Ornithinicoccus hortensis gen. nov., sp. nov., a soil actinomycete which contains L-ornithine. Int J Syst Bacteriol 49, 1717-1724.

Groth, I., Schumann, P., Schütze, B., Augsten, K. \& Stackebrandt, E. (2002). Knoellia sinensis gen. nov., sp. nov. and Knoellia subterranea sp. nov., two novel actinobacteria isolated from a cave. Int J Syst Evol Microbiol 52, 77-84.

Huss, V. A. R., Festl, H. \& Schleifer, K. H. (1983). Studies on the spectrophotometric determination of DNA hybridization from renaturation rates. Syst Appl Microbiol 4, 184-192.

Imamura, Y., Ikeda, M., Yoshida, S. \& Kuraishi, H. (2000). Janibacter brevis sp. nov., a new trichloroethylene-degrading bacterium isolated from polluted environments. Int J Syst Evol Microbiol 50, 1899-1904.

Jahnke, K.-D. (1992). Basic computer program for evaluation of spectroscopic DNA renaturation data from GILFORD system 2600 spectrometer on a PC/XT/AT type personal computer. J Microbiol Methods 15, 61-73.

Kalakoutskii, L. V., Kirillova, I. P. \& Krassilnikov, N. A. (1967). A new genus of the Actinomycetales - Intrasporangium gen. nov. $J$ Gen Microbiol 48, 79-85.

Kämpfer, P. \& Kroppenstedt, R. M. (1996). Numerical analysis of fatty acid patterns of coryneform bacteria and related taxa. Can J Microbiol 42, 989-1005.

Kroppenstedt, R. M. (1985). Fatty acid and menaquinone analysis of actinomycetes and related organisms. In Chemical Methods in Bacterial Systematics, pp. 173-199. Edited by M. Goodfellow \& D. E. Minnikin. New York: Academic Press.

Martin, K., Schumann, P., Rainey, F. A., Schuetze, B. \& Groth, I. (1997). Janibacter limosus gen. nov., sp. nov., a new actinomycete with meso-diaminopimelic acid in the cell wall. Int J Syst Bacteriol 47, 529-534.

Maszenan, A. M., Seviour, R. J., Patel, B. K. C., Schumann, P., Burghardt, J., Tokiwa, Y. \& Stratton, H. M. (2000). Three isolates of novel polyphosphate-accumulating Gram-positive cocci, obtained from activated sludge, belong to a new genus, Tetrasphaera gen. nov., and description of two new species, Tetrasphaera japonica sp. nov. and Tetrasphaera australiensis sp. nov. Int J Syst Evol Microbiol 50, 593-603.

Mesbah, M., Premachandran, U. \& Whitman, W. B. (1989). Precise measurement of the $\mathrm{G}+\mathrm{C}$ content of deoxyribonucleic acid by high-performance liquid chromatography. Int J Syst Bacteriol 39, 159-167.

Minnikin, D. E., O'Donnell, A. G., Goodfellow, M., Alderson, G., Athalye, M., Schaal, A. \& Parlett, J. H. (1984). An integrated procedure for the extraction of isoprenoid quinones and polar lipids. J Microbiol Methods 2, 233-241.

Prauser, H., Schumann, P., Rainey, F. A., Kroppenstedt, R. M. \& Stackebrandt, E. (1997). Terracoccus luteus gen. nov., sp. nov., an LL-diaminopimelic acid-containing coccoid actinomycete from soil. Int J Syst Bacteriol 47, 1218-1224.

Rainey, F. A., Ward-Rainey, N., Kroppenstedt, R. M. \& Stackebrandt, E. (1996). The genus Nocardiopsis represents a phylogenetically coherent taxon and a distinct actinomycete lineage: proposal of Nocardiopsaceae fam. nov. Int J Syst Bacteriol 46, 1088-1092.

Sasser, M. (1990). Identification of Bacteria by Gas Chromatography of Cellular Fatty Acids. MIDI technical note no. 101. Newark, DE: MIDI Inc.

Schleifer, K. H. \& Kandler, O. (1972). Peptidoglycan types of bacterial cell walls and their taxonomic implications. Bacteriol Rev 36, 407-477.

Schmid, A., Rothe, B., Altenbuchner, J., Ludwig, W. \& Engesser, K.-H. (1997). Characterization of three distinct extradiol dioxygenases involved in mineralization of dibenzofuran by Terrabacter $\mathrm{sp}$. strain DPO360. J Bacteriol 179, 53-62.

Stackebrandt, E. \& Schumann, P. (2000). Description of Bogoriellaceae fam. nov., Dermacoccaceae fam. nov., Rarobacteraceae fam. nov. and Sanquibacteraceae fam. nov. and emendation of some families of the suborder Micrococcineae. Int J Syst Evol Microbiol 50, 1279-1285.

Stackebrandt, E., Rainey, F. A. \& Ward-Rainey, N. L. (1997). Proposal for a new hierarchic classification system, Actinobacteria classis nov. Int J Syst Bacteriol 47, 479-491. 
Stanier, R. Y., Palleroni, N. J. \& Doudoroff, M. (1966). The aerobic pseudomonads: a taxonomic study. J Gen Microbiol 43, 159-271.

Strubel, V., Rast, H. G., Fietz, W., Knackmuss, H.-J. \& Engesser, K. H. (1989). Enrichment of dibenzofuran utilizing bacteria with high co-metabolic potential towards dibenzodioxin and other anellated aromatics. FEMS Microbiol Lett 58, 233-238.
Tamaoka, J. \& Komagata, K. (1984). Determination of DNA base composition by reverse-phase high-performance liquid chromatography. FEMS Microbiol Lett 25, 125-128.

Yoon, J.-H., Lee, K.-C., Kang, S.-S., Kho, Y. H., Kang, K. H. \& Park, Y.-H. (2000). Janibacter terrae sp. nov., a bacterium isolated from soil around a wastewater treatment plant. Int J Syst Evol Microbiol 50, $1821-1827$. 